ECONOMICS

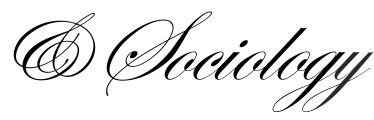

Pietrzak, M. B., Fałdziński, M., Balcerzak, A. P., Meluzín, T., Zinecker, M. (2017), Short-term Shocks and Long-term Relationships of Interdependencies Among Central European Capital Markets, Economics and Sociology, Vol. 10, No. 1, pp. 61 -

77. DOI: 10.14254/2071-789X.2017/10-1/5

\begin{abstract}
Michał Bernard Pietrzak, Nicolaus Copernicus University, Torun, Poland,

E-mail:michal.pietrzak@umk.pl

Marcin Fałdziński,

Nicolaus Copernicus University,

Torun, Poland,

E-mail:marf@umk.pl
\end{abstract}

Adam P. Balcerzak, Nicolaus Copernicus University, Torun, Poland,

E-mail: adam.balcerzak@umk.pl

Tomáš Meluzín, Brno University of Technology, Brno, Czech Republic, E-mail:melurint@vutbr.cr.

\author{
Marek Zinecker, \\ Brno University of Technology, \\ Brno, Czech Republic, \\ E-mail: rinecker@fbm.vutbr.cz.
}

Received: July, 2016

1st Revision: November, 2016

Accepted: December, 2016

DOI: $10.14254 / 2071-$

789X.2017/10-1/5

JEL Classification: G15, C58

\section{SHORT-TERM SHOCKS AND LONG- TERM RELATIONSHIPS OF INTERDEPENDENCIES AMONG CENTRAL EUROPEAN CAPITAL MARKETS}

\begin{abstract}
The article focuses on the problem of interdependences among Central European capital markets. The main aim of this research is to identify longterm interdependences among Austrian, Czech, Hungarian and Polish capital markets and the market of Germany. Additionally, the impact of short-term shocks on these markets is under evaluation. In the first step of the research the interdependencies among the capital markets in the years 1997-2015 were verified. For this purpose the DCC-GARCH model with the conditional t-distribution was used. In the second step, an analysis of cointegration for the interdependencies among the markets was carried out. The authors proposed to include conditional variances of the analysed markets as additional explanatory variables in the cointegration analysis. As the conditional variance most often reflects the impact of short-term shocks, the proposed approach allowed to take into account shortterm market shocks in the cointegration analysis. The results enabled to identify long-term path for the course of the interdependences among markets of Germany, Austria, Czech Republic, Hungary and Poland. The mentioned Central European capital markets make a group of markets characterized with similar long-term path, which are focused around the dominant market of Germany.
\end{abstract}

Keywords: cointegration analysis, DCC-GARCH model, conditional variance, conditional correlation, short-term shocks.

\title{
Introduction
}

Globalisation phenomenon and changes in the main development determinants of industrialised countries lead to growing interdependencies among economies (Balcerzak, 2009, 2016a; Janda et al., 2013; Pohulak-Żołędowska, 2016; Kondratiuk-Nierodzińska, 2016; Pietrzak and Balcerzak, 2016a; Balcerzak and Pietrzak, 2016a, 2017). That factor can be especially significant in the case of capital markets (Meluzín and Zinecker, 2016; Meluzín et al., 2016; Osińska et al., 2016). Last global financial crisis has proved the growing influence of "financisation" of economy on the situation on labour markets (Glazar and Strielkowski, 
2010; Müller-Frączek and Pietrzak, 2011; Pietrzak and Balcerzak, 2016b), macroeconomic fiscal stability (Hadaś-Dyduch, 2015; Miklaszewicz, 2016; Majerová, 2016; Lajtkepová, 2016; Balcerzak, 2016b; Balcerzak and Rogalska, 2016; Balcerzak et al., 2016) and sustainability of whole economies (Pietrzak et al., 2014; Pietrzak and Balcerzak, 2016c; Balcerzak and Pietrzak, 2016b). As a result, identification of international linkages among markets and analysis of their variability over time is the condition for effective management of risk associated to potential negative influence of global capital markets (Arshanapalli et al., 1995; Andersen et al., 1999; Baur, 2003; Pericoli and Sbracia, 2003; Engle, 2009; Billio and Caporin, 2010; Syllignakis and Kouretas, 2011; Baek and Jun, 2011; Karanasos et al., 2014; Reboredo et al., 2015; Heryán and Ziegelbauer, 2016; Gawrońska-Nowak and Grabowski, 2016). It is of great importance both for policy makers at macroeconomic level and managers operating in international environment from microeconomic perspective. As a result, in spite of relatively big supply of research on this subject, the identification of linkages among markets, analysis of changes in the strength of these dependencies must be considered as an important field of scientific research (Forbes and Rigobon, 2002; Corsetti et al., 2005).

The main aim of this article is to analyse interdependences among Austrian, Czech, Hungarian and Polish capital markets and the market of Germany. The analysis is carried out both in terms of the impact of short-term shocks and long-term path of these markets. Two hypotheses are proposed in the article. The first one states that there is a similar formation process of long term interdependencies among German and pointed Central European capital markets. According to the second hypothesis it is assumed that volatility of individual capital markets significantly affects the changes of strength of the interdependencies among analysed markets.

The article is a continuation and further development of previous research efforts of the authors (Fałdziński and Pietrzak, 2015; Fałdziński et al., 2016; Zinecker et al., 2016; Balcerzak et al., 2016). In this article in order to measure relationships among markets conditional correlations calculated on the basis of the results of estimation of parameters of $\operatorname{ARMA}(\mathrm{p}, \mathrm{q})$-APARCH(1,1)-DCC model were used. To verify the hypotheses of the article cointegration analysis for the conditional correlations among selected markets on the basis of VECM model was performed. In the case of specification of VECM model authors have proposed a novel approach in the form of adding the conditional variances for the capital markets as an additional explanatory variable. The inclusion of the variances in the VECM model allowed to assess the impact of short-term shocks on the change of the strength of interdependencies among the analysed capital markets.

\section{Literature Review}

As it has been already stated in the introduction, last global financial crisis with the problem of contagion effect was an important factor that has resulted in growing interests in potential consequences of interdependencies among financial markets. The research in that field usually takes a global perspective, where the econometric models are applied to analysis of wide set of international stock indices, or it has regional character from the perspective of world economy, where the main attention is given to interdependencies among markets from a group of countries with similar fundamental characteristics.

Starting with the global perspective one can paint to a research provided by Lupu (2015) who concentrated on the problem of contagion during the global financial crisis. The research was based on the narrow definition of contagion, where a considerable increase in stock market comovement is treated as a response to a shock affecting a given country. The research was conducted for 49 stock indices in the years 2000-2015, where the daily correlations for a time lapse 2000-2015 were obtained with application DCC GARCH model. 
This enabled to analyse the changes in the values of the obtained correlations with a Markov switching model with two states. The research provided an argument in favour of the contagion phenomenon on the national capital markets.

Avdoulas et al. (2016) provide an interesting research concerning a specific group of Eurozone peripheral countries (Portugal, Ireland, Italy, Greece and Spain), which were especially touched by the negative consequences of the global financial crisis. The authors assessed the presence of linear and nonlinear dynamic causal relations among the stock markets. They showed that the linear causal linkages for the return time series tend to disappear after filtering. On the other hand, nonlinear causal relationships are statistically significant for all cases even after multivariate GARCH filtering. The results could be useful in assessing the extent of financial or banking integration in the Eurozone and could explain a significant part of the(non)predictability of these markets.

Deltuvaite (2016) took into consideration the problem of the spillover effect from the major stock markets on the 11 CEECs countries (Bulgaria, Czech Republic, Croatia, Estonia, Hungary, Latvia, Lithuania, Poland, Romania, Slovakia, and Slovenia). In the research there were also analysed types of shocks causing the cross-border contagion risk transmission to the CEECs markets. In the research DCC-GARCH model was used. The highest degree of global and regional integration of the stock indices was observed in Polish, Czech and Hungarian markets, which was interpreted as a consequence of relatively higher development level of these markets comparing to other mentioned CEECs. Additionally, the collapse of Lehman Brothers bank was pointed as the most significant shock transmitted to CEECs stock markets.

The problem of the impact of the sovereign debt crisis on three Central and Eastern European markets (Czech Republic, Hungary, and Poland) was analysed by Bein and Tuna (2015), who also applied DCC GARCH model framework. They concentrated on the volatility transmission and conditional correlation changes in the aftermath of the European crisis against the backdrop of GIPSI countries (Greece, Ireland, Portugal, Spain and Italy) as the group that have experienced substantial decline in their equity markets. To compare the conditional correlation and account for indirect transmission, United Kingdom, Germany, and France (EU 3 ), were also taken into account. The research showed a significant spillover effect from the GIPSI and EU 3 to the three CEE. Greek market was an exception in this case. In the group of CEE the stock market of Poland has shown a significantly higher level of weighted average conditional correlation as compared to Hungary and the Czech Republic.

Dajcman (2012) verified the comovement and spillover dynamics between the returns of the Czech, Polish, Hungarian and Slovenian stock indices, and some developed European markets (Austrian, French, German, and United Kingdom). He used DCC GARCH model and Granger causality tests on wavelet transformed returns series for the period April 1997-May 2010. The research especially concentrated on the problem of influence of the financial crises and the accession of the Czech Republic to the EU on the comovement between the Czech and European stock markets. The analysis confirmed the comovement between the Czech and other stock market returns was time-varying. Additionally, the author showed a significant return spillovers between the Czech and European markets, which should be considered as a multiscale phenomenon.

The problem of interdependencies among financial markets is also often analysed within the cointegration framework. Kostanjcar et al. (2014) verified the dynamic linkages between the developed equity markets of USA, Japan and Britain and the emerging markets of South-East Europe: Croatia, Slovenia and Hungary. In the article differences between the interdependences during the period of the dot-com bubble and during the time of last financial crisis were taken into consideration. The long-run relationships between indices were analyzed with the Johansen cointegration test. Then, both the short-term and long-term movements in equity markets with a VECM model were verified. Finally, the causality 
between the series was tested with the Granger causality test. The analysis confirmed that the South-East Europe equity markets have become more integrated with the most important markets of the world, which affects negatively their potential for risk diversification.

Dukic and Dukic (2015) analysed interdependencies of stock indexes in Southeastern European countries: Slovenia, Croatia, Serbia, Montenegro, Republic of Srpska, Macedonia and Bulgaria. The context of the research was related to a dilemma of banking institutions concerning the possibilities to buy back the shares so as to slow down the share price decrease on the markets. The authors prove that in the case of analysed shallow capital markets, it is not possible to successfully use the share buyback to stop or reduce the share price fall.

The problem of diversification benefits in the context of integration of South-Eastern European markets (SEE): Bulgaria, Croatia, Romania, Slovenia and Turkey with developed markets of Germany, United Kingdom and the USA was taken into consideration by Guidi and Ugur (2014). They used static and dynamic cointegration analysis. The static approach showed that the SEE markets are cointegrated with the German and the UK markets in the years 20002013, but not with the USA market. Additionally, the dynamic analysis showed the existence of time-varying cointegration among the SEE and the developed markets. The researchers confirmed the diversification benefits from September 2007 to June 2013 despite evidence of dynamic cointegration during most of the crisis period from September 2008 to May 2010.

In the next section of the article the methodology proposed for research on the interdependences among Austrian, Czech, Hungarian and Polish capital markets, and the market of Germany is presented, where for specification of VECM model authors have proposed to add the conditional variances for the capital markets as an additional explanatory variable.

\section{Research Methodology}

DCC-GARCH model enables to analyse interdependences among markets by estimating the time-varying conditional correlation. Due to two-stage estimation method proposed by Engle $(2002,2009)$ the DCC-GARCH model enables to apply other specifications of the GARCH family models. This factor is currently often considered as it main advantage.

The ARMA(p,q)-APARCH(1,1)-DCC model (Dinget al., 1993) with conditional tdistribution can be given as follow:

$$
\begin{gathered}
\left(\mathbf{1}-\boldsymbol{\Phi}_{1} B-\ldots-\boldsymbol{\Phi}_{p} B^{p}\right) \mathbf{Y}_{\mathbf{t}}=\mathbf{c}+\left(\mathbf{1}+\mathbf{\Theta}_{1} B+\ldots+\mathbf{\Theta}_{q} B^{q}\right) \boldsymbol{\eta}_{\mathbf{t}} \\
\boldsymbol{\eta}_{\mathbf{t}} \mid \mathbf{F}_{t-1} \sim t\left(0, \mathbf{D}_{\mathbf{t}} \mathbf{R}_{\mathbf{t}} \mathbf{D}_{\mathbf{t}}, v\right) \\
\mathbf{D}_{\mathbf{t}}^{\mathbf{2}}=\operatorname{diag}\left\{\mathbf{H}_{\mathbf{t}}\right\}, \mathbf{H}_{\mathbf{t}}=\mathbf{V}_{\mathbf{t}-\mathbf{1}}\left(\boldsymbol{\eta}_{\mathbf{t}}\right), \\
\mathbf{H}_{\mathbf{t}}^{\boldsymbol{\delta}}=\mathbf{A}_{\mathbf{0}}+\mathbf{A}_{\mathbf{1}}\left(\left|\boldsymbol{\eta}_{\mathbf{t}-\mathbf{1}}\right|-\gamma \boldsymbol{\eta}_{\mathbf{t}-\mathbf{1}}\right)^{\boldsymbol{\delta}}+\mathbf{A}_{\mathbf{2}} \mathbf{H}_{\mathbf{i}, \mathbf{t}-\mathbf{1}}^{\boldsymbol{\delta}}, \\
\boldsymbol{\varepsilon}_{\mathbf{t}}=\mathbf{D}_{\mathbf{t}}^{-1} \boldsymbol{\eta}_{\mathbf{t}}, \\
\mathbf{R}_{\mathbf{t}}=\operatorname{diag}\left\{\mathbf{Q}_{\mathbf{t}}\right\}^{-1 / 2} \mathbf{Q}_{\mathbf{t}} \operatorname{diag}\left\{\mathbf{Q}_{\mathbf{t}}\right\}^{-1 / 2}, \\
\mathbf{Q}_{\mathbf{t}}=\overline{\mathbf{R}}(1-a-b)+a \boldsymbol{\varepsilon}_{\mathbf{t}-\mathbf{1}} \boldsymbol{\varepsilon}_{\mathbf{t}-\mathbf{1}}^{\prime}+b \mathbf{Q}_{\mathbf{t}-\mathbf{1}},
\end{gathered}
$$


where:

$\mathbf{Y}_{\mathbf{t}}$ - the multivariate process of returns,

$\mathbf{H}_{\mathrm{i}, \mathrm{t}}-$ the conditional variance matrix for $\mathrm{i}$-th returns, where $i=1, \ldots, N$,

$\mathbf{V}_{\mathbf{t}-\mathbf{1}}\left(\boldsymbol{\eta}_{\mathbf{t}}\right)$ - the covariance matrix of the residuals $\boldsymbol{\eta}_{\mathbf{t}}$,

$\mathbf{R}_{\mathbf{t}}$ - the time-varying conditional correlation matrix,

$\mathbf{Q}_{\mathbf{t}}$ - a positive-definite quasi correlation matrix for each time period,

c - the constant,

$\boldsymbol{\Phi}, \boldsymbol{\Theta}$ - the parameters of the $\operatorname{ARMA}(\mathrm{p}, \mathrm{q})$ part,

$\mathbf{A}_{0}, \mathbf{A}_{1}, \mathbf{A}_{2}, \boldsymbol{\delta}>0,-1<\gamma<1$ - the parameters of the conditional variance equation,

$a, b$ - the parameters of the conditional correlation equation,

$v>2$ - the degrees of freedom,

$B$ - is the backshift operator,

$\overline{\mathbf{R}}$ - the unconditional correlation matrix which consists of $\bar{\rho}_{i, j}$.

In the ARMA(p,q)-APARCH(1,1)-DCC model the conditional variance is dependent on lagged conditional variance and on squared returns with the consideration of conditional means, where $\boldsymbol{\delta}$ plays the role of Box-Cox transformation of matrix $\mathbf{H}_{\mathbf{t}}$, while $\boldsymbol{\gamma}$ reflects the leverage effect. On the other hand, in the case of conditional correlation equation standardised residuals from the conditional variance equations and lagged conditional correlations make explanatory variables. Additionally, in order to guarantee matrix $\mathbf{H}_{\mathbf{t}}$ to be positive definite the parameters $a, b$ must fulfil the following conditions $a \geq 0, b \geq 0$ and $a+b<1$.

Parameters of the ARMA(p,q)-APARCH(1,1)-DCC model can be estimated with application of the maximum likelihood method. Similar to the DCC-GARCH model, the twostage estimation method can be applied (Engle, 2002, 2009). The log-likelihood function for $\mathrm{t}$-distribution can be written as follow:

$$
\begin{aligned}
L(\theta)= & T\left[\ln \Gamma\left(\frac{v+N}{2}\right)-\left[\ln \Gamma\left(\frac{v}{2}\right)\right]-\frac{N}{2} \ln ((v-2) \pi)\right] \\
& -0.5 \sum_{t=1}^{T} \ln \left|\mathbf{H}_{\mathbf{t}}\right|-\frac{v+N}{2} \sum_{t=1}^{T} \ln \left(1+\left(\mathbf{Y}_{\mathbf{t}}-\boldsymbol{\varepsilon}_{\mathbf{t}}\right) \mathbf{H}_{\mathbf{t}}^{-1}\left(\mathbf{Y}_{\mathbf{t}}-\mathbf{\varepsilon}_{\mathbf{t}}\right) /(v-2)\right)
\end{aligned}
$$

Estimation of parameters of $\operatorname{ARMA}(\mathrm{p}, \mathrm{q})-\mathrm{APARCH}(1,1)-\mathrm{DCC}$ model enables to determine the conditional variances and conditional correlations for the pairs of analysed indices. In the next step the analysis of cointegration can be made and VECM model (Vector Error Correction Model) can be proposed (Engle and Granger, 1987; Boswijk and Doornik, 2004). The cointegration analysis allows to test whether any interrelations among analyzed markets form a specific formal system of linkages and how this system is formed.

VECM model is a VAR model for cointegrated processes. Let's assume $\mathrm{p}$ rank VAR model with deterministic component $d_{i}$, which can be written as follow:

$$
y_{t}=D d_{t}+A_{1} y_{t-1}+\ldots+A_{p} y_{t-p}+\varepsilon_{t}
$$


where: $y_{t}$ is $N$-dimensional stochastic process, $A_{i}$ for $i=1 \ldots p$ are matrixes of parameters $N \times N, D$ is a matrix of parameters for deterministic variables and $\varepsilon_{t}$ is $\mathrm{N}$-dimensional white noise.

When one writes VAR model in the form of first differences of $y_{t}$ process, it can be given as follow:

$$
\Delta y_{t}=D d_{t}+\Pi y_{t-1}+\sum_{i=1}^{p-1} \Gamma_{i} \Delta y_{t-i}+\varepsilon_{t}
$$

where: $\Pi=\sum_{i=1}^{p} A_{i}-I$ a $\Gamma_{i}=-\sum_{j=t+1}^{p} A_{j}$.

The rank " $r$ " of a matrix $\Pi$ determines the interpretation of the model given with equation 9. When it equals $N$, the process $y_{t}$ is not integrated $I(0)$. When the rank $r$ equals 0 , the process $y_{t}$ is integrated of order one $I(1)$, but it is not cointegrated. There is a cointegration when the rank $r$ is between $0<r<N$ and the matrix $\Pi$ can be written as $\alpha \beta^{\prime}$. Matrix $\alpha$ is a matrix of adjustments matrix and $\beta$ is a cointegrating vector (Fałdziński et al., 2016).

To test cointegration the existence of $\Pi$ matrix is verified and then the rank $r$ of matrix $\Pi$ is calculated. The number of cointegrating vectors can be determined through checking the statistical significance of characteristic roots of matrix $\Pi$. The rank of matrix $\Pi$ equals the number of characteristic roots, which are different from zero. In the absence of cointegrating vector the rank of the matrix $\Pi$ and all the characteristic roots are equal to zero.

In order to determine the number of cointegrating vectors Johansen $(1988,1991,1995)$ procedure can be conducted, where a maximum eigenvalue test and trace test are used. The described procedure is an iterative process and it is applied until the rejection of the null hypothesis. In the first step of the procedure the null hypothesis that there is no cointegrating vector is adopted (lack of cointegration $(r=0)$, against the alternative that there is at least one such vector $(\mathrm{r}>0)$. In the case of rejection of the null hypothesis, the following assumptions are made successively: $\left(H_{0}: r=1, H_{1}: r>1\right),\left(H_{0}: r=2, H_{1}: r>2\right)$ which in the next steps results in successive increasing of $r$ (Fałdziński et al., 2016). The testing procedure ends in the case of the absence of evidence that enable to reject the null hypothesis. The max-eigenvalue test statistics is characterized with nonstandard distribution, where the critical values can be found in the work of Osterwald-Lenum (1992). The trace test can be used in an analogous manner to the max-eigenvalue test (Johansen, 1995).

It is possible to conduct the analysis of cointegration of conditional correlations received from $\operatorname{ARMA}(\mathrm{p}, \mathrm{q})-\operatorname{APARCH}(1,1)-\mathrm{DCC}$. Therefore, the following long term equation for the conditional correlation can be written:

$$
\rho_{t, y_{0}}=\psi_{0}+\psi_{1} \rho_{t, y_{1}}+\ldots+\psi_{n} \rho_{t, y_{n}}+\xi_{t}
$$

where: $\rho_{t, y_{0}}, \ldots, \rho_{t, y_{n}}$ are conditional correlations received from $\operatorname{ARMA}(\mathrm{p}, \mathrm{q})-\operatorname{APARCH}(1,1)-\mathrm{DCC}$ and $\xi_{t}$ is a random component.

Thus, for the long-term equation appropriate short-term equation can be created: 


$$
\begin{aligned}
{\left[\begin{array}{c}
\Delta \rho_{t, y_{0}} \\
\vdots \\
\Delta \rho_{t, y_{n}}
\end{array}\right] } & {\left[\begin{array}{c}
\text { const }_{0} \\
\vdots \\
\text { const }_{n}
\end{array}\right]+\left[\begin{array}{c}
\gamma_{01} \\
\vdots \\
\gamma_{n 1}
\end{array}\right] \cdot\left[\begin{array}{c}
\Delta \rho_{t-1, y_{0}} \\
\vdots \\
\Delta \rho_{t-1, y_{n}}
\end{array}\right]+\ldots+\left[\begin{array}{c}
\gamma_{0 m} \\
\vdots \\
\gamma_{n m}
\end{array}\right] \cdot\left[\begin{array}{c}
\Delta \rho_{t-m, y_{0}} \\
\vdots \\
\Delta \rho_{t-m, y_{n}}
\end{array}\right]+\left[\begin{array}{c}
\lambda_{0} \\
\vdots \\
\lambda_{n}
\end{array}\right]\left[\begin{array}{c}
H_{t, y_{0}} \\
\vdots \\
H_{t, y_{n}}
\end{array}\right]+} \\
& +\left[\begin{array}{c}
\varphi_{0} \\
\vdots \\
\varphi_{n}
\end{array}\right]\left[\begin{array}{c}
E C M_{t-1} \\
\vdots \\
E C M_{t-1}
\end{array}\right]+\left[\begin{array}{c}
\eta_{t, y_{0}} \\
\vdots \\
\eta_{t, y_{0}}
\end{array}\right]
\end{aligned}
$$

where time-delayed first differences of conditional correlations, conditional variance $H_{t, y_{0}}, \ldots, H_{t, y_{n}}$ and $E C M_{t-1}$ responsible for long-term relationship are taken as the explanatory variables. In the short-term equation, the authors suggest to include a conditional variance $H_{t, y_{0}}, \ldots, H_{t, y_{n}}$ for the analysed capital markets as additional explanatory variables. The values of the conditional variances are obtained in the process of estimation of parameters of GARCH volatility models. This approach can be justified because the spill over or contagion effects of increased (decreased) volatility in one market often involve increasing volatility and interdependencies among other markets. In the case of cointegration analysis the proposed approach allows to take into account short-term market shocks whose impact is most often reflected in the course of the conditional variance.

\section{Results of empirical research for Central European capital markets}

In regard to the aim of the article in the proposed empirical research time series for five stock indices (ATX, BUX, PX 50, WIG and DAX) were used. For each of the indexes daily rate of return were calculated from 1 July 1997 to 30 September 2015. It gave a total of 4592 observations. The data was obtained from: http://www.finance.yahoo.com.

In the first step parameters of $\operatorname{ARMA}(1,0)-\mathrm{APARCH}(1,1)-\mathrm{DCC}$ model were estimated. The maximum likelihood method with the t-student conditional distribution was applied here. The ARMA(1,0) were applied on the basis of the information BIC criterion. The results are presented in table 1 . The constant $c$ in ARMA model was statistically insignificant for the DAX, WIG20, BUX, PX 50 indices. And for all indices remaining parameters of the ARMA(1,0)-APARCH(1,1)-DCC model were statistically significant. All the conditions relating to the parameters are met: ${ }^{a_{1}+a_{2}<1}$ and $a+b<1$ (He and Teräsvirta, 1999).

\begin{tabular}{|c|c|c|c|c|c|}
\hline Parameter & Estimate & p-value & Parameter (stock index) & Estimate & p-value \\
\hline$c(\mathrm{ATX})$ & 0.036902 & 0.0293 & $c(\mathrm{BUX})$ & 0.020704 & 0.3099 \\
\hline$\phi_{1}(\mathrm{ATX})$ & 0.074098 & 0.0000 & $\phi_{1}(\mathrm{BUX})$ & 0.042274 & 0.0079 \\
\hline$a_{0}(\mathrm{ATX})$ & 0.035256 & 0.0000 & $a_{0}(\mathrm{BUX})$ & 0.070578 & 0.0003 \\
\hline$a_{1}(\mathrm{ATX})$ & 0.089898 & 0.0000 & $a_{1}(\mathrm{BUX})$ & 0.087048 & 0.0000 \\
\hline$a_{2}(\mathrm{ATX})$ & 0.897685 & 0.0000 & $a_{2}(\mathrm{BUX})$ & 0.878330 & 0.0000 \\
\hline$\delta(\mathrm{ATX})$ & 0.540560 & 0.0000 & $\delta(\mathrm{BUX})$ & 0.252455 & 0.0000 \\
\hline$\gamma(\mathrm{ATX})$ & 1.220582 & 0.0000 & $\gamma(\mathrm{BUX})$ & 2.131098 & 0.0000 \\
\hline$c(\mathrm{DAX})$ & 0.024387 & 0.1475 & $c(\mathrm{PX} 50)$ & 0.012785 & 0.5042 \\
\hline
\end{tabular}

Table 1. The results of the estimation of the ARMA(1,0)-APARCH(1,1)-DCC model 
RECENT ISSUES IN ECONOMIC DEVELOPMENT

\begin{tabular}{|c|c|c|c|c|c|}
\hline$\phi_{1}(\mathrm{DAX})$ & 0.013716 & 0.3607 & $\phi_{1}$ (PX 50) & -0.041773 & 0.0087 \\
\hline$a_{0}(\mathrm{DAX})$ & 0.032835 & 0.0000 & $a_{0}(\mathrm{PX} 50)$ & 0.016730 & 0.0018 \\
\hline$a_{1}(\mathrm{DAX})$ & 0.074613 & 0.0000 & $a_{1}(\mathrm{PX} 50)$ & 0.070415 & 0.0000 \\
\hline$a_{2}(\mathrm{DAX})$ & 0.913169 & 0.0000 & $a_{2}(\mathrm{PX} \mathrm{50)}$ & 0.936638 & 0.0000 \\
\hline$\delta(\mathrm{DAX})$ & 0.781262 & 0.0000 & $\delta(\mathrm{PX} 50)$ & 0.458083 & 0.0002 \\
\hline$\gamma(\mathrm{DAX})$ & 1.208809 & 0.0000 & $\gamma(\mathrm{PX} 50)$ & 1.015445 & 0.0000 \\
\hline$c(\mathrm{WIG})$ & 0.006969 & 0.7262 & $\bar{\rho}_{21}$ & 0.180610 & 0.0005 \\
\hline$\phi_{1}(\mathrm{WIG})$ & 0.035541 & 0.0329 & $\bar{\rho}_{31}$ & 0.373935 & 0.0000 \\
\hline$a_{0}(\mathrm{WIG})$ & 0.020432 & 0.0034 & $\bar{\rho}_{41}$ & 0.231364 & 0.0000 \\
\hline$a_{1}(\mathrm{WIG})$ & 0.064028 & 0.0000 & $\bar{\rho}_{51}$ & 0.288679 & 0.0000 \\
\hline$a_{1}(\mathrm{WIG})$ & 0.928637 & 0.0000 & $\bar{\rho}_{32}$ & 0.410700 & 0.0000 \\
\hline$\delta(\mathrm{WIG})$ & 0.179623 & 0.0001 & $\bar{\rho}_{42}$ & 0.456930 & 0.0000 \\
\hline$\gamma(\mathrm{WIG})$ & 1.963301 & 0.0000 & $\bar{\rho}_{52}$ & 0.394525 & 0.0000 \\
\hline $\bar{\rho}_{53}$ & 0.631439 & 0.0000 & $\bar{\rho}_{43}$ & 0.447238 & 0.0000 \\
\hline $\bar{\rho}_{54}$ & 0.409439 & 0.0000 & $v$ & 10.363757 & 0.0000 \\
\hline$a$ & 0.006244 & 0.0000 & $b$ & 0.991793 & 0.0000 \\
\hline
\end{tabular}

Source: own estimation based on time series form: http://www.finance.yahoo.com.

After estimation of the parameters of the model ARMA(1,0)-APARCH(1,1)-DCC values of conditional correlations for the next pair of indices were calculated. The correlations for a particular pair of indices indicate the strength of the interrelationships among the two capital markets. They also show upward or downward trends of these interrelationships over time. In accordance with the aim of the article, the conditional correlations were used in the cointegration analysis.

Figure 1 presents the conditional correlations between the DAX index and ATX, BUX, PX 50 and WIG indices. It shows that the relationships among German capital market and the markets of Austria, Czech Republic, Poland and Hungary are shaped similarly. It can be said that since 2004 until 2012 shocks occurring on the German market are transferred in a similar way to Austrian, Czech, Polish and Hungarian markets. This means that the valuation of indices on any stock exchange is largely dependent on the situation on the other markets. 


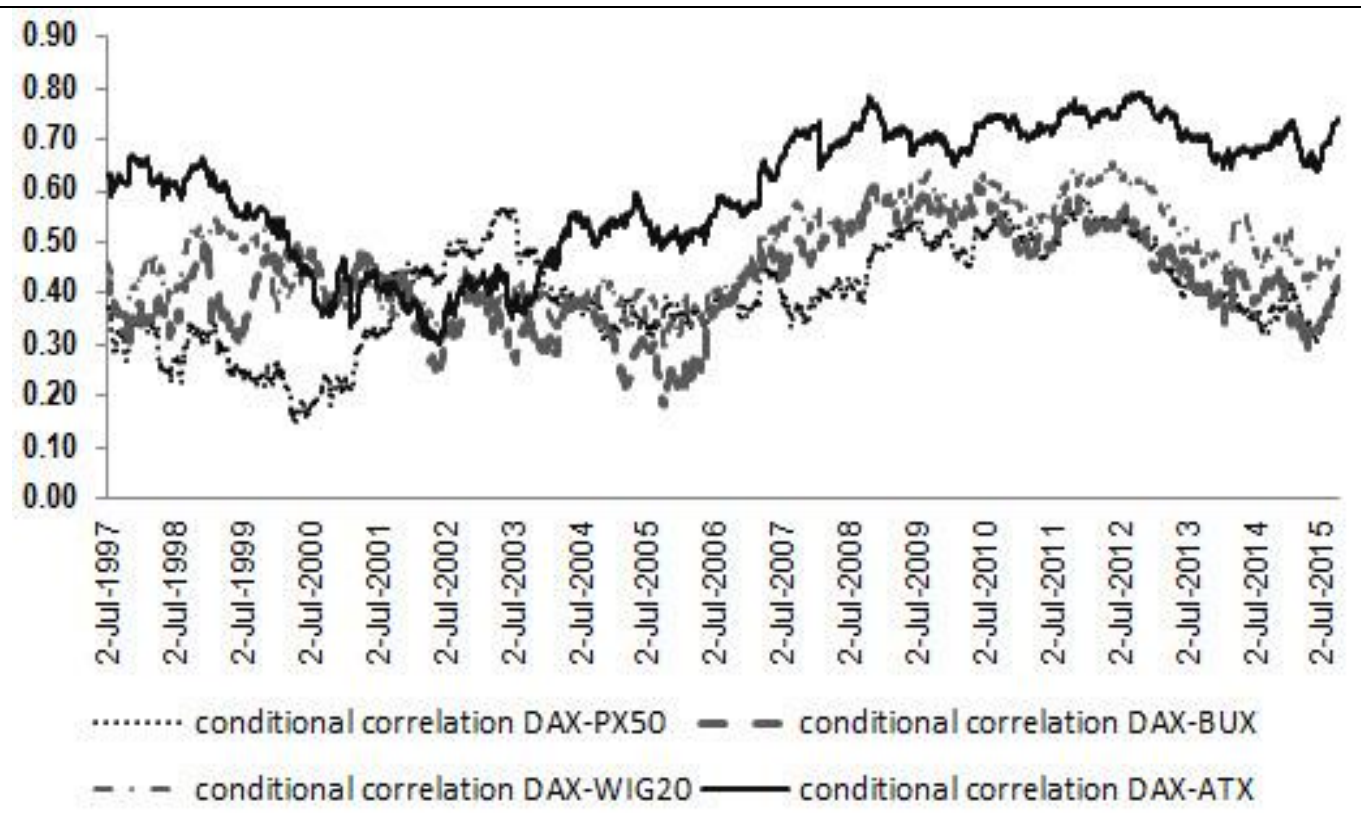

Figure 1 The conditional correlation between selected markets Source: own research.

In a further step an analysis of cointegration of conditional correlations obtained from the ARMA(1,0)-APARCH(1,1)-DCC model was conducted. For this purpose, firstly the time series of conditional correlations were tested for stationarity with application of PhillipsPerron test (Phillips and Perron, 1988). All the time series of the conditional correlations were integrated of order 1.

Next, the Johansen procedure was applied, which enabled to test the number of cointegrating relationships. Table 2 presents the results of the test for the number of cointegrating vectors (MacKinnon et al., 1999). The result of the max-eigenvalue test and the trace test indicate one cointegrating vector.

Table 2. The results of Johansen procedure

\begin{tabular}{lcccc}
\hline \multirow{2}{*}{$\begin{array}{c}\text { Hypothesized } \\
\text { number of cointegrating } \\
\text { vectors }\end{array}$} & \multicolumn{4}{c}{ Max-Eigenvalue } \\
\cline { 2 - 5 } & Eigenvalue & Statistic & Critical Value 5\% & p-value \\
\hline None & 0.0075 & 64.07 & 47.85 & 0.0008 \\
\hline At most 1 & 0.0038 & 29.48 & 29.79 & 0.0543 \\
\hline At most 2 & 0.0021 & 11.61 & 15.49 & 0.1763 \\
\hline At most 3 & 0.0003 & 1.768 & 3.84 & 0.1835 \\
\hline $\begin{array}{c}\text { Hypothesized } \\
\text { number of cointegrating } \\
\text { vectors }\end{array}$ & Eigenvalue & Statistic & Critical Value 5\% & p-value \\
\cline { 2 - 5 } None & 0.0075 & 34.59 & 27.58 & 0.0053 \\
\hline At most 1 & 0.0038 & 17.86 & 21.13 & 0.1349 \\
\hline At most 2 & 0.0021 & 9.84 & 14.26 & 0.2221 \\
\hline At most 3 & 0.0003 & 1.768 & 3.84 & 0.1835 \\
\hline
\end{tabular}

Source: own estimation. 
After determination of the number of cointegrating vectors long-term equation for $\operatorname{VECM}(2)$ model was estimated. As a result the following empirical model was obtained:

$$
\rho_{t, D A X-B U X}=-0.69+\operatorname{l[6.5628]}_{t, 8 A X-P X 50}-\rho_{[-4.7068]}^{1.44} \rho_{t, D A X-W I G}+\underset{[1.2935]}{0.31} \rho_{t, D A X-A T X}+\xi_{t}
$$

where: t-statistics are given in square brackets.

Parameters of the long-term equation are statistically significant except for the parameter for $\rho_{t, D A X-A T X}$. The equation indicates that the conditional correlation between the DAX and BUX indices is significant, positive relation with respect to the conditional correlation between DAX and PX 50 indices and a significant negative relation with respect to the conditional correlation between DAX and WIG indices. In the long term a selected group of capital markets forms one cointegrating relationship with the dominant role of German capital market. The received negative assessment of the value of the parameter for $\rho_{t, D A X-W G}$ variable can indicate the existence of differences in time in reaction of the capital markets of Hungary and Poland to changes in the situation on the German capital market.

In the last step of the analysis estimation of parameters of short-term equation given with formula 12 was conducted. The results are presented in Table 3, where estimations of parameters and t-statistics for the four equations are given. The parameters for the variable $E C M_{t-1}$ are statistically significant in the equations for $\Delta \rho_{D A X-P X 50}, \Delta \rho_{D A X-B U X}$ and $\Delta \rho_{D A X-A T X}$. The negative values of estimations of these parameters indicate the existence of the process of reaching long term path for given pairs of markets. However, the parameter for $E C M_{t-1}$ variable in equation for $\Delta \rho_{D A X-W G}$ is statistically insignificant. This may indicate that German capital market is not the only one that influences the situation on Polish capital market in terms of short-term deviations.

Table 3. Vector Error Correction Estimates

\begin{tabular}{|c|c|c|c|c|c|}
\hline \multicolumn{2}{|c|}{ Equation } & \multirow{2}{*}{$\begin{array}{r}\Delta \rho_{D A X-B U X} \\
-0,00073\end{array}$} & \multirow{2}{*}{$\begin{array}{l}\Delta \rho_{D A X-W I G} \\
-0,00068\end{array}$} & \multirow{2}{*}{$\begin{array}{c}\Delta \rho_{D A X-P X 50} \\
-0,00065\end{array}$} & \multirow{2}{*}{$\begin{array}{c}\Delta \rho_{D A X-A T X} \\
-0,00018\end{array}$} \\
\hline const & estimate & & & & \\
\hline conist & t-statistics & 4,06111 & 3,78889 & 3,58889 & 1,60909 \\
\hline \multirow{2}{*}{$E C M_{t-1}$} & estimate & $-0,00437$ & 0,00008 & $-0,00528$ & $-0,00162$ \\
\hline & t-statistics & 4,50825 & 0,08289 & 5,33131 & 2,70167 \\
\hline \multirow{2}{*}{$\Delta \rho_{t-1, D A X-B U X}$} & estimate & $-0,00088$ & 0,01640 & 0,02626 & $-0,00049$ \\
\hline & t-statistics & 0,05361 & 1,01122 & 1,58073 & 0,04852 \\
\hline \multirow{2}{*}{$\Delta \rho_{t-2, D A X-B U X}$} & estimate & $-0,00938$ & 0,00316 & $-0,02289$ & 0,00275 \\
\hline & t-statistics & 0,57311 & 0,19464 & 1,37702 & 0,27028 \\
\hline \multirow{2}{*}{$\Delta \rho_{t-1, D A X-W G G}$} & estimate & 0,02029 & 0,00992 & $-0,02377$ & $-0,00730$ \\
\hline & t-statistics & 1,21947 & 0,60091 & 1,40663 & 0,70707 \\
\hline \multirow{2}{*}{$\Delta \rho_{t-2, D A X-W I G}$} & estimate & 0,01285 & $-0,02916$ & 0,00679 & $-0,01222$ \\
\hline & t-statistics & 0,77246 & 1,76834 & 0,40178 & 1,18267 \\
\hline \multirow{2}{*}{$\Delta \rho_{t-1, D A X-P X} 50$} & estimate & $-0,00131$ & $-0,00951$ & $-0,01344$ & $-0,00780$ \\
\hline & t-statistics & 0,08704 & 0,63740 & 0,87932 & 0,83469 \\
\hline \multirow{2}{*}{$\Delta \rho_{t-2, D A X-P X} 50$} & estimate & $-0,01330$ & $-0,00161$ & 0,00073 & $-0,00555$ \\
\hline & t-statistics & 0,88398 & 0,10757 & 0,04784 & 0,59443 \\
\hline$\Delta \rho_{t-1, D A X-A T X}$ & estimate & 0,00185 & 0,01330 & $-0,02395$ & $-0,01933$ \\
\hline
\end{tabular}


RECENT ISSUES IN ECONOMIC DEVELOPMENT

\begin{tabular}{cccccc}
\hline & t-statistics & 0,07386 & 0,53423 & 0,93943 & 1,23964 \\
\hline \multirow{2}{*}{$\Delta \rho_{t-2, D A X-A T X}$} & estimate & $-0,03263$ & 0,03832 & 0,00075 & $-0,02736$ \\
\cline { 2 - 6 } & t-statistics & 1,29980 & 1,53973 & 0,02958 & 1,75471 \\
\hline \multirow{2}{*}{$H_{t, \text { DAX }}$} & \multicolumn{5}{c}{ Conditional Variances $H_{t, y_{0}}, \ldots, H_{t, y_{n}}$} \\
& estimate & 0,00030 & 0,00022 & 0,00037 & 0,00017 \\
\cline { 2 - 6 } & t-statistics & 4,64615 & 3,43750 & 5,60606 & 4,32500 \\
\hline \multirow{2}{*}{$H_{t, \text { WIG }}$} & estimate & 0,00040 & 0,00042 & 0,00006 & 0,00012 \\
\cline { 2 - 6 } & t-statistics & 3,61818 & 3,82727 & 0,57182 & 1,74627 \\
\hline \multirow{2}{*}{$H_{t, \text { PX50 }}$} & estimate & $-0,00020$ & $-0,00016$ & $-0,00014$ & $-0,00018$ \\
\cline { 2 - 6 } & t-statistics & 4,63636 & 3,62791 & 3,27273 & 6,48148 \\
\hline \multirow{2}{*}{$H_{t, \text { BUX }}$} & estimate & $-0,00015$ & $-0,00009$ & $-0,00005$ & $-0,00004$ \\
\cline { 2 - 6 } & t-statistics & 3,19149 & 1,97660 & 1,10000 & 1,38621 \\
\hline \multirow{2}{*}{$H_{t, \text { ATX }}$} & estimate & 0,00017 & 0,00006 & 0,00014 & 0,00013 \\
\cline { 2 - 6 } & t-statistics & 2,76190 & 0,90484 & 2,18750 & 3,43590 \\
\hline
\end{tabular}

Source: own estimation.

Adding conditional variance $H_{t, \mathrm{DAX}}, \ldots, H_{t, \mathrm{ATX}}$ to the short-term equation turned out to be justified because most of the parameters for these variables are statistically significant. The values of the estimates of parameters for $H_{t, D A X}, H_{t, W G}$ and $H_{t, A T X}$ are positive. It means that in a short period an increase in strength of interrelations among the capital markets of Germany and other markets can be present, due to an increase in volatility in one of the capital markets of Germany, Poland or Austria. In the case of $H_{t, \mathrm{PX} 50}, H_{t, \mathrm{Bux}}$ variables negative estimates of parameters were obtained. This may indicate the existence of time-delayed changes in the volatility of Czech and Hungarian markets under the influence of changes in the interdependence among Polish, Czech, Hungarian and Austrian markets and the capital market of Germany. The delayed reaction on the Czech and Hungarian markets may be the evidence of continuous adaptation of these markets to the situation in the whole group of analyzed markets.

Most of the parameters for $\Delta \rho_{t-1, \mathrm{DAX}-\mathrm{BUX}}, \ldots, \Delta \rho_{t-2, \mathrm{DAX}-A T X}$ are not statistically significant in the short-term equation. This means that the delayed first differences of conditional correlations are not able to describe short-term interdependences adequately. This confirms the validity of the adoption of conditional variances as an additional explanatory variable for the analysed capital markets in short-term equation 12.

Additionally, impulse response analysis was performed. The results are presented on Figure 2. An impulse in the case of conditional correlation has a visible positive effect in the case of the same pair of capital markets (eg. DAX-BUX) and a small effect in the case of different pairs. The only exception is a pair DAX-WIG, for which it has a significant positive impact on other pairs of conditional correlations. This means that changes in the conditional correlation for a pair DAX-WIG lead to changes in the conditional correlations among the capital markets of Germany and other markets under evaluation. The impulse response analysis confirms the conclusions that have been drawn on the basis of estimates of short-term equation. 

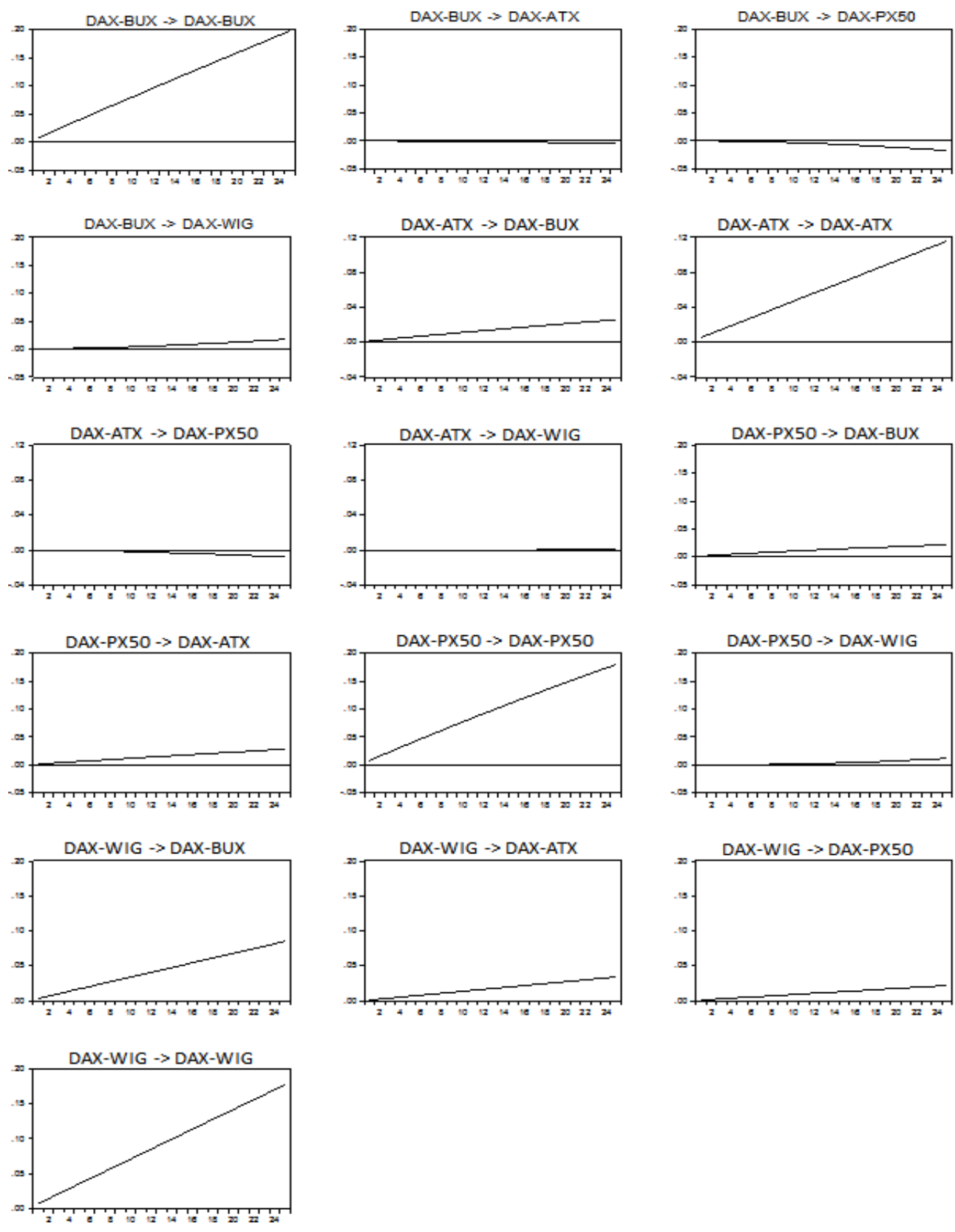

Figure 2. Accumulated response to Cholesky one standard deviation innovations Source: own estimation.

\section{Conclusions}

The article concentrated on the problem of interrelationships among capital markets, whose strength and importance are constantly increasing due to the globalization phenomenon. As a result, the identification of inter-linkages among markets is currently an important scientific problem in economics. Research in this filed can be helpful in forming strategies for potential crisis situations.

The aim of the article was to analyse the interdependencies among selected Central European capital markets. In order to verify the research hypotheses cointegration analysis for the conditional correlations among German, Austrian, Polish, Czech and Hungarian markets was performed. In the cointegration analysis the authors proposed a novel approach, where 
the conditional variances as additional explanatory variables were included in the VECM model. The proposed method enabled to capture the impact of short-term market shocks on the development of interdependences among the analysed markets.

The obtained results allow to identify the long-term path for the course of interdependences among the capital markets of Germany, Austria, Poland, Czech and Hungary. This means verifying the research hypothesis that pointed at the occurrence of similar developments in the evolution of interrelationships among German capital market and the markets of other countries in Central Europe.

The results of the estimation of specification of the expanded VECM model enabled to verify second hypothesis. In the case of Germany, Austria and Poland it was shown that the variability of these capital markets has a significant impact on the development of interdependences among the studied markets.

The conducted research results indicate that capital markets of Germany, Poland, Austria, Czech Republic and Hungary experienced similar developments in the observed period and that German capital market played the dominant role within the whole region.

\section{References}

Andersen, T. G., Bollerslevb, T., \& Langed, S. (1999), Forecasting Financial Market Volatility: Sample Frequency Vis-à-vis Forecast Horizon, Journal of Empirical Finance, 6(5), pp. 457-477, DOI: 10.1016/S0927-5398(99)00013-4.

Arshanapalli, B., Doukasb, J., \& Langc, L. H. P. (1995), Pre and Post-October 1987 Stock Market Linkages Between U.S. and Asian Markets, Pacific-Basin Finance Journal, 3(1), pp. 57-73, DOI: 10.1016/0927-538X(94)00025-3.

Avdoulas, C., Bekiros, S., \& Boubaker, S. (2016), Detecting Nonlinear Dependencies in Eurozone Peripheral Equity Markets: A Multistep Filtering approach, Economic Modelling, 58, pp. 580-587, DOI: 10.1016/j.econmod.2016.02.001.

Baek, I.-M., \& Jun, J. (2011), Testing Contagion of the 1997-98 Crisis in Asian Stock Markets with Structural Breaks and Incubation Periods, Journal of Asian Economics, 22(5), pp. 356-368, DOI:10.1016/j.asieco.2011.05.005.

Balcerzak, A. P. (2009), Effectiveness of the Institutional System Related to the Potential of the Knowledge Based Economy, Ekonomista, 6, pp. 711-739.

Balcerzak, A. P. (2016a), Technological Potential of European Economy. Proposition of Measurement with Application of Multiple Criteria Decision Analysis, Montenegrin Journal of Economics, 12(3), pp. 7-17, DOI: 10.14254/1800-5845.2016/12-3/1.

Balcerzak, A. P. (2016b), Fiscal Burden in the European Union Countries, Economic Annals XXI, 161(9-10), pp. 4-6, DOI: https://doi.org/10.21003/ea.V161-01.

Balcerzak, A. P., Fałdziński, M., Meluzín, T., Pietrzak, M. B., \& Zinecker, M. (2016), Interdependence among Capital Markets of Germany, Poland and Baltic States. Application of DCC-GARCH Model, In: M. Čulík (ed.), Managing and Modeling Financial Risks, 8th International Scientific Conference Proceedings (Part I), Ostrava: VŠB-Technical University of Ostrava, pp. 28-36.

Balcerzak, A. P. \& Pietrzak, M. B. (2016a), Structural Equation Modeling in Evaluation of Technological Potential of European Union Countries in the Years 2008-2012, In: M. Papież \& S. Śmiech (eds.), The 10th Professor Aleksander Zelias International Conference on Modelling and Forecasting of Socio-Economic Phenomena. Conference Proceedings, Cracow: Foundation of the Cracow University of Economics, pp. 9-18, retrieved from: http://econpapers.repec.org/bookchap/pesecchap/10.htm.

Balcerzak, A. P. \& Pietrzak, M. P. (2016b), Application of TOPSIS Method for Analysis of Sustainable Development in European Union Countries, In: T. Loster \& T. Pavelka 
(eds.), The 10th International Days of Statistics and Economics. Conference Proceedings. September 8-10, 2016, Prague: Libuse Macakova, Melandrium, pp. 82-92, retrieved form: http://econpapers.repec.org/bookchap/pesecchap/19.htm.

Balcerzak, A. P. \& Pietrzak, M. B. (2017), Human Development and Quality of Institutions in Highly Developed Countries, In: M. H. Bilgin, H. Danis, E. Demir, \& U. Can (eds.), Financial Environment and Business Development. Proceedings of the 16th Eurasia Business and Economics Society, Springer International Publishing, pp. 231-241, DOI 10.1007/978-3-319-39919-5_18.

Balcerzak, A. P., Pietrzak, M. B., \& Rogalska, E. (2016), Fiscal Contractions in Eurozone in the years 1995-2012: Can non-Keynesian effects be helpful in future deleverage process? In: M. H. Bilgin, H. Danis, E. Demir, \& U. Can (eds.), Business Challenges in the Changing Economic Landscape - Vol. 1. Proceedings of the 14th Eurasia Business and Economics Society, Springer International Publishing, pp. 483-496, DOI 10.1007/978-3-319-22596-8_35.

Balcerzak, A. P., \& Rogalska, E. (2016), Non-Keynesian Effects of Fiscal Consolidations in Central Europe in the Years 2000-2013, In: M. H. Bilgin, \& H. Danis (eds.), Entrepreneurship, Business and Economics - Vol. 2. Proceedings of the 15th Eurasia Business and Economics Society, Springer International Publishing, pp. 271-282, DOI 10.1007/978-3-319-27573-4_18.

Baur, D. (2003), Testing for Contagion - Mean and Volatility Contagion, Journal of Multinational Financial Management, 13, pp. 405-422.

Bein, M. A. \& Tuna, G. (2015), Volatility Transmission and Dynamic Correlation Analysis between Developed and Emerging European Stock Markets during Sovereign Debt Crisis, Romanian Journal of Economic Forecasting, 18(2), pp. 61-80.

Billio, M., \& Caporin, M. (2010), Market Linkages, Variance Spillover and Correlation Stability: Empirical Evidences of Financial Contagion, Computational Statistics \& Data Analysis, 54(11), pp. 2443-2458.

Boswijk, H. P., \& Doornik, J. A. (2004), Identifying, Estimating and Testing Restricted Cointegrated Systems: An Overview, Statistica Neerlandica, 58(4), pp. 440-465.

Corsetti, G., Pericoli, M., \& Sbracia, M. (2005), Some Contagion, Some Interdependence: More Pitfalls in Testing for Contagion, Journal of International Money and Finance, 24, pp. 1177-1199.

Dajcman, S. (2012), The Dynamics of Return Comovement and Spillovers Between the Czech and European Stock Markets in the Period 1997, Finance a úvěr-Czech Journal of Economics and Finance, 62(4), pp. 368-390.

Deltuvaite, V. (2016), Transmission of Shocks Through Stock Markets Channel: the Case of the CEECs, Procedia Economics and Finance, 39, pp. 292-297, DOI: 10.1016/S22125671(16)30326-4.

Ding, Z., Granger, C. W. J., \& Engle, R. F. (1993), A Long Memory Property of Stock Market Returns and a New Model, Journal of Empirical Finance, 1(1), pp. 83-106.

Dukic, D., \& Dukic, M. (2015), Interdependencies of Markets in Southeastern Europe and Buyback of Shares on Shallow Capital Markets: The Application of Cointegration and Causality Tests, Panoeconomicus, 62(4), pp. 469-491, DOI: 10.2298/PAN1504469D.

Engle, R. F., \& Granger, C. W. J. (1987), Co-integration and Error Correction: Representation, Estimation and Testing, Econometrica, 55(2), pp. 251-276.

Engle, R. F. (2002), Dynamic Conditional Correlation: A Simple Class of Multivariate Generalized Autoregressive Conditional Heteroskedasticity Models, Journal of Business \& Economic Statistics, 20, pp. 339-350.

Engle, R. F. (2009), Anticipating Correlations A New Paradigm for Risk Management, Princeton and Oxford: Princeton University Press. 
He, C., \& Teräsvirta, T. (1999), Higher-order Dependence in the General Power ARCH Process and a Special Case, Stockholm School of Economics, Working Paper Series in Economics and Finance, No. 315.

Fałdziński, M., \& Pietrzak, M. B. (2015), The Multivariate DCC-GARCH Model with Interdependence Among Markets in Conditional Variances' Equations, Przeglad Statystyczny, 62(1), pp. 397-413.

Fałdziński, M., Balcerzak, A. P., Meluzín, T., Pietrzak, M. B., \& Zinecker, M. (2016), Cointegration of Interdependencies Among Capital Markets of Chosen Visegrad Countries and Germany, In: A. Kocourek, M. Vavrousek (eds.), $34^{\text {th }}$ International Conference Mathematical Methods in Economics MME 2016 Conference Proceedings, Liberec: Technical University of Liberec, pp. 189-194, retrieved form: http://econpapers.repec.org/bookchap/pesecchap/16.htm.

Forbes, K., \& Rigobon, R. (2002), No Contagion, Only Interdependence: Measuring Stock Market Comovements, Journal of Finance, 57(5), pp. 2223-2261.

Gawrońska-Nowak, B., \& Grabowski, W. (2016), Using Genetic Algorithm in Dynamic Model of Speculative Attack, Equilibrium. Quarterly Journal of Economics and Economic Policy, 11(2), pp http://dx.doi.org/10.12775/EQUIL.2016.013.

Glazar, O., \& Strielkowski, W. (2010), Turkey and the European Union: possible incidence of the EU accession on migration flows, Prague Economic Papers, 19(3), pp. 218-235, doi: https://doi.org/10.18267/j.pep.373.

Guidi, F., \& Ugur, M. (2014), An analysis of South-Eastern European stock markets: Evidence on cointegration and portfolio diversification benefits, Journal of International Financial Markets Institutions\& Money, 30(1), pp. 119-136, DOI: 10.1016/j.intfin.2014.01.007.

Hadaś-Dyduch, M. (2015), Polish Macroeconomic Indicators Correlated-prediction with Indicators of Selected Countries, In: M. Papież\& S. Śmiech (eds.), The 9th Professor AleksanderZelias International Conference on Modelling and Forecasting of SocioEconomic Phenomena, Conference Proceedings, Cracow: Foundation of the Cracow University of Economics.

http://www.finance.yahoo.com.

Heryán, T., \& Ziegelbauer, J. (2016), Volatility of Yields of Government Bonds Among GIIPS Countries During the Sovereign Debt Crisis in the Euro Area, Equilibrium. Quarterly Journal of Economics and Economic Policy, 11(1), pp. 61-74, DOI: http://dx.doi.org/10.12775/EQUIL.2016.003.

Janda, K., Rausser, G., \& Strielkowski, W. (2013), Determinants of Profitability of Polish Rural Micro-Enterprises at the Time of EU Accession, Eastern European Countryside, 19, pp. 177-217, doi: https://doi.org/10.2478/eec-2013-0009.

Johansen, S. (1988), Statistical Analysis of Cointegration Vectors, Journal of Economic Dynamics and Control, 12(2-3), pp. 231-254.

Johansen, S. (1991), Estimation and Hypothesis Testing of Cointegration Vectors in Gaussian Vector Autoregressive Models, Econometrica, 59, pp. 1551-1580.

Johansen, S. (1995), Likelihood-based Inference in Cointegrated Vector Autoregressive Models, Oxford: Oxford University Press.

Karanasos, M., Yfanti, S., \& Karoglou, M. (2014), Multivariate FIAPARCH Modelling of Financial Markets with Dynamic Correlations in Times of Crisis, International Review of Financial Analysis, 45, pp. 332-349, DOI: http://dx.doi.org/10.1016/j.irfa.2014.09.002.

Kondratiuk-Nierodzińska, M. (2016), New Knowledge Generation Capabilities and Economic Performance of Polish Regions, Equilibrium. Quarterly Journal of Economics and 


$\begin{array}{lllll}\text { Economic Policy, } & \text { 11(3), } & \text { pp. } & \text { 451-471, }\end{array}$
http://dx.doi.org/10.12775/EQUIL.2016.021.

Kostanjcar, Z., Jeren, B., \& Juretic, Z. (2014), Modelling the Relationship Between Developed Equity Markets and Emerging Equity Markets, In: A. Serguieva, D. Maringer, V. Palade \& R. J. Almeida (eds.), 2014 IEEE Conference on Computational Intelligence for Financial Engineering \& Economics (CIFER), London: IEEE, pp. 270-277.

Lajtkepová, E. (2016), Differences and Similarities in the Indebtedness of EU Member States after Last Financial Crisis, Oeconomia Copernicana, 7(4), pp. 551-563, DOI: http://dx.doi.org/10.12775/OeC.2016.031.

Lupu, I. (2015), European Stock Markets Correlations in a Markov Switching Framework, Romanian Journal of economic Forecasting, 18(3), pp. 103-119.

MacKinnon, J. G., Haug, A. A., \&Michelis, L. (1999), Numerical Distribution Functions of Likelihood Ratio Tests for Cointegration, Journal of Applied Econometrics, 14, pp. 563577.

Majerová, I. (2016), The Impact of Some Variables on the VAT Gap in the Member States of the European Union, Oeconomia Copernicana, 7(3), pp. 339-355, DOI: http://dx.doi.org/ 10.12775/OeC.2016.020.

Meluzín, T., \& Zinecker, M. (2016), Trends in IPOs: The Evidence from CEE Capital Markets, Equilibrium. Quarterly Journal of Economics and Economic Policy, 11(2), pp. 327-341, DOI: http://dx.doi.org/10.12775/EQUIL.2016.015.

Meluzín, T., Zinecker, M., \& Lace, N. (2016), Going Public: Key Factors to Consider by IPO Candidates on Emerging Markets of Poland and the Czech Republic, Engineering Economics, 27(4), pp. 392-404, DOI: http://dx.doi.org/10.5755/j01.ee.27.4.14755.

Miklaszewicz, S. (2016), Sovereign Debt Crisis of the Eurozone Countries, Oeconomia Copernicana, 7(3), pp. 357-373, DOI: http://dx.doi.org/10.12775/OeC.2016.021.

Müller-Frączek, I., \& Pietrzak, M. B. (2011), Przestrzenna analiza stopy bezrobocia w Polsce w latach 2004-2008, In: P. Jedlicka (ed.), Hradeckéekonomické dny 2011. Ekonomickýrozvoj a management regionů, Hradec Králové: Gaudeamus, pp. 205-209.

Osińska, M., Dobrzyński, A., \& Shachmurove, Y. (2016), Performance of American and Russian Joint Stock Companies on Financial Market. A Microstructure Perspective, Equilibrium. Quarterly Journal of Economics and Economic Policy, 11(4), pp. 819-851, DOI: http://dx.doi.org/10. 12775/EQUIL.2016.037.

Osterwald-Lenum, M. (1992), A Note with Quantiles of the Asymptotic Distribution of the Maximum Likelihood Cointegration Rank Test Statistics, Oxford Bulletin of Economics and Statistics, 54, pp. 461-472.

Pericoli, M., \& Sbracia, M. (2003), A Primer on Financial Contagion, Journal of Economic Surveys, 17(4), pp. 571-608.

Phillips, P., \& Perron, P. (1988), Testing for a Unit Root in Time Series Regression, Biometrica, 75(2), pp. 335-346.

Pietrzak, M. B. \& Balcerzak, A. P (2016a), Quality of Human Capital and Total Factor Productivity in New EU Member States, In: T. Loster \& T. Pavelka (eds.), The 10th International Days of Statistics and Economics. Conference Proceedings. September 810, 2016, Prague: Libuse Macakova, Melandrium, pp. 1492-1501, retrieved form: http://econpapers.repec.org/bookchap/pesecchap/20.htm.

Pietrzak, M. B., \& Balcerzak, A. P. (2016b), A Spatial SAR Model in Evaluating Influence of Entrepreneurship and Investments on Unemployment in Poland, In: Proceedings of the International Scientific Conference Quantitative Methods in Economics Multiple Criteria Decision Making XVIII, Vratna: Letra Interactive, pp. 303-308, retrieved form: http://econpapers.repec.org/bookchap/pesecchap/13.htm. 
Pietrzak, M. B., \& Balcerzak, A. P. (2016c), Assessment of Socio-Economic Sustainability in New European Union Members States in the years 2004-2012, In: M. Papież \& S. Śmiech (eds.), The 10th Professor Aleksander Zelias International Conference on Modelling and Forecasting of Socio-Economic Phenomena. Conference Proceedings, Cracow: Foundation of the Cracow University of Economics, pp. 120-129, retrieved from: http://econpapers.repec.org/bookchap/pesecchap/11.htm.

Pietrzak, M. B., Wilk J.,. Kossowski T., \& Bivand, R. (2014), The Identification of Spatial Dependence in the Analysis of Regional Economic Development - Join-count Test Application, In: M. Papież \& S. Śmiech (eds.), Proceedings of the 8th Professor Aleksander Zelias International Conference on Modelling and Forecasting of SocioEconomic Phenomena, Cracow: Foundation of the Cracow University of Economics, Cracow, pp. 135-144.

Pohulak-Żołędowska, E. (2016), Innovation in Contemporary Economies, Oeconomia Copernicana, 7(3), pp. 451-466, DOI: http://dx.doi.org/10.12775/OeC.2016.026.

Reboredo, J. C., Tiwari, A. K., \& Albulescu, C. T. (2015), An Analysis of Dependence Between Central and Eastern European Stock Markets, Economic Systems, 39, pp. 474490.

Syllignakis, M. N., \& Kouretas, G. P. (2011), Dynamic Correlation Analysis of Financial Contagion: Evidence from the Central and Eastern European Markets, International Review of Economics and Finance, 20(4), pp. 717-732, DOI: 10.1016/j.iref.2011.01.006.

Zinecker, M., Balcerzak, A. P., Fałdziński, M., Meluzín, T., \& Pietrzak, M. B. (2016), Application of DCC-GARCH Model for Analysis of Interrelations Among Capital Markets of Poland, Czech Republic and Germany, In: Proceedings of the International Scientific Conference Quantitative Methods in Economics Multiple Criteria Decision Making XVIII, Vratna: Letra Interactive, pp. 416-421, retrieved form: http://econpapers.repec.org/bookchap/pesecchap/12.htm. 